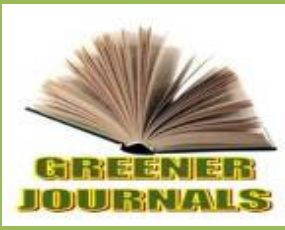

\title{
Determinants of Supply of Funds to Agricultural Sector from Formal Sources in Nigeria from 1992 to 2012
}

\section{Ogbonna S. I. and *Osondu C. K.}

\author{
Department of Agricultural Economics and Extension Abia State University, Umuahia Campus, \\ PMB 7010, Umuahia, Abia state, Nigeria. \\ E- mails: ogbonna101@gmail.com
}

\section{ARTICLE INFO}

Article No.: 051815074

DOI: 10.15580/GJAS.2015.3.051815074

Submitted: $18 / 05 / 2015$

Accepted: $22 / 06 / 2015$

Published: 29/06/2015

${ }^{*}$ Corresponding Author

Osondu C. K.

E-mail: osonducharles87

@gmail.com

Keywords:

Agricultural sector, bank loans, credit supply, transaction cost
The study was carried out in Nigeria. Specifically the study analyzed performance of formal credit sources by amount of loan disbursed to agriculture from 1992 to 2012 and determined factors that influenced volume of funds supplied to agricultural sector from formal sources in Nigeria from 1992 to 2012. Time series data, covering the periods of $1992-2012$, culled basically from the Central Bank of Nigeria's Statistical Bulletin were used. The data collected were analyzed using descriptive statistics and two Stage Least Square regression technique. The result of the performance of the formal credit sources by amount of loan disbursed to agriculture showed that commercial banks under the ACGS performed better than the Microfinance banks and Bank of Agriculture which was evident by the amount disbursed (N48.8bn) by commercial banks, with Microfinance banks disbursing $\mathbf{N}$ $32.3 \mathrm{~m}$ and $\mathrm{BOA}$ disbursing $\mathrm{N} 14.7 \mathrm{~m}$ to agriculture over the period under review. The 2SLS results showed that the volume of funds supplied to agricultural production from formal sources was affected positively by interest rate and commercial banks' liquidity ratio and negatively by banks' cash reserve ratio (CRR) and index of World Agricultural Commodity Prices. These variables were statistically significant at $\mathbf{1 . 0} \%$ level of probability except the index of World Agricultural Commodity Prices which was significant at $5.0 \%$ alpha level. The diagnostic statistics posted $R^{2}$ and F- ratio values of 0.7904 and 6.46 respectively with Durbin Watson estimates of 2.323311. The federal government must consider interest rate regulation as a veritable tool for making credit accessible to farmers at affordable levels where transaction costs will not be too high as to discourage farmers willing to invest or expand their investment to withdraw from doing so. 


\section{INTRODUCTION}

\subsection{Background Information}

Credit supply to agriculture is particularly justified when farmers have very low savings capacity, poorly developed rural financial markets and availability of appropriate farm technologies whose adoption is constrained by shortage of funds. These conditions hold in Nigerian agriculture. In this realization, Nigerian governments, supported by multi- lateral and bi-lateral aid agencies, have devoted considerable financial resources to supplying cheap credit facilities to farmers and other rural entrepreneurs in a myriad of institutional settings (Nwaru, et al., 2004).

Government has different institutions or channels through which finances are supplied to farmers. Each of these institutions has its own mandate that runs parallel to others. The major institutions so far established to provide and channel credit facilities to the agricultural sector are the defunct Nigerian Agricultural and Co-operative Bank (NACB), 1973, River Basin Development Authority (RBDA), 1977, Directorate of Food Roads and Rural Infrastructure (DFRRI), 1986 and Nigerian Agricultural Insurance Corporation (NAIC), 1987. Others are Agricultural Credit guarantee scheme fund (ACGSF), 1977 and the Agricultural Credit Support Scheme (ACSS), 2006 (World Bank, 2009). These institutions had been complemented by - programmes such as Agricultural Development Programme (ADP) 1975, Operation Feed the Nation (OFN) 1976, Rural Banking Programme (1977), Green Revolution, 1980, defunct Family Economic Advancement Programme (FEAP), 1997 and the National Poverty Eradication programme (NAPEP), 1999.

The Agricultural Credit Guarantee Scheme Fund (ACGSF) established in 1977 was an agricultural programme that has special interest in facilitating supply of credit. The scheme was established to mobilize funds from the banking sector for rural development by guaranteeing loans by commercial banks for investment in agriculture to minimize risk involved in financing the sector. Other formal sources of funds to agricultural sector include agricultural banks and microfinance banks. However, the vicissitudes of the financial sector appears to be inseparable from the performance of the ACGSF in meeting up with its goals of mobilizing adequate credit for the agricultural sector. According to findings by Onoja et al., (2013), immediate past (previous years) credit volume guaranteed by ACGSF (ACGSF past) exerted significant influence on the supply of current credit to the agricultural sector. This demonstrates the relevance of the ACGSF in improving agricultural finance level in Nigerian economy.

Mandatory credit allocation to agriculture was abolished on October 1, 1996 . Consequently, the volume of bank funds channeled to agricultural sector decreased forcing the Federal Government to introduce a new agricultural credit scheme in March 2006 in which tax waiver is given on interest earned by banks on loans to agricultural sector and reduction of interest rate to farmers through government subsidy (CBN, 2006a). In a further bid to increase credit supply to agricultural sector the Federal Government in 2008 created the special fund tagged "The Commercial Agricultural Credit Scheme - CACS" in 2008 with an initial grant of N200 billion by the Federal government was part of the deal to make sure banks lend to farmers. The disbursement of the fund was to be handled by three apex banks under the supervision of the Central Bank of Nigeria (CBN) Asuquo, et al., (2014).

The Central Bank of Nigeria however has observed that inadequate funds are supplied to the agricultural sector (CBN, 2010). Sustenance of funding to farmers requires a robust commitment on the part of formal supply chain of credit to agriculture. Farming as a business demands judicious provision of huge funds. However, formal credit sources have not been able to recognize genuine farmers and work with their commitment in offering service to the sector. There have been problems of giving loans meant for agricultural development to people who are not into farming resulting into neglect or poor management of formal funds for agriculture.

Several Studies have dealt with credit supply issues in Nigeria (Onoja, et. al., 2012; Akpan, 1999; and Oguamanam, 1996). Onoja et al., (2012) dealt on contributions of financial sector reforms and credit supply to Nigerian Agricultural sector (1978-2009) and recognized interest rate regulation as a veritable tool for making credit accessible to farmers at affordable levels. Akpan (1999) used time series data of 33 years to analyse the contribution of government expenditures to the growth process in Nigeria and concluded that Government's capital expenditure on agriculture though not statistically significant had positive influence on investment. However none of these studies analyzed performance of formal credit sources in terms of amount of loan disbursed to agricultural sector within the period under review. Information provided by this study will be a good addition to literature to meet the needs of researchers on similar topics. This study had its specific objectives to: (i) analyze performance of formal credit sources by amount of loan disbursed to agriculture within the period under review and (ii) determine factors that influenced volume of funds supplied to agricultural sector from formal sources in Nigeria from 1992 to 2012. The study was anchored on the following null hypothesis:

$\mathrm{Ho}_{1}$ : Total farm credit accessed from commercial banks, NACRDB and micro finance bank is not positively influenced by interest rate (lending rate) in percentage (IR), Cumulative foreign private investment in Agriculture in naira (FPI-Agr), Index of Agricultural Gross Domestic Product (IAGDP), Liquidity ratio of commercial banks in percentage (LR), Cash Reserve Ratio of commercial banks in percentage (CRR), Minimum Rediscount Rate 
of commercial banks in percentage (MRR), Index of world Agricultural commodity prices in naira per tonne (WP) and Time Trend variable in years (T).

\section{LITERATURE REVIEW}

\subsection{Overview of Agricultural Credit and Financing in Nigeria}

In Nigeria, agricultural credit is necessary to enable the farmers take advantage of new technologies in the form of farm machinery, pay for such items as improved varieties of seeds and livestock, fertilizers, pesticides, labour and other running costs. It is in the realization of the fact that credit is a critical factor in agricultural development that for most governments in developing countries, the channeling of bank lending to agriculture has increasingly become an important policy instrument for increasing agricultural output particularly among the rural poor (Egbe,1990).

One of the major objectives of the local, state and federal Government has been that of credit provision and efficient management of agricultural credit. This objective was considered necessary by taking into recognition the important role banks play in the supply of funds to farmers for increased agricultural production. The commitment to prudent lending to agricultural sector is an important and crucial issue in the global banking sector today (Ejike et al, 2013).

In 1986 government deemphasized the direct food production policy and adopted an integrated approach that combined real sector with rural development. As a result of this new agricultural development thrust, government established Directorate for Food, Road and Rural Infrastructure (DFRRI) to construct and maintain feeder roads. However, by 1988 government agricultural policy thrust was directed at providing support services while all aspects of agricultural production and marketing including input supply as well as agricultural mechanization were handled by the private sector.

It was also evident from the increasing food supply shortfalls, rising cost of food processing and delivering, decreasing foreign exchange earnings from agricultural exports that agriculture is not given the needed attention for economic development (CBN, 2003). Inadequacy of government funding of agricultural projects and programmes has been observed by researchers because lack of strong evidence of growth promotion externalities by deepening food insecurity, social inequality, rural poverty and hunger are issues of funding (Ogiri, 2004).

For agricultural practice to be meaningful, one of the enabling factors is addressed by availability of adequate credit to finance agricultural production. The agricultural lending market in any country is made up of the participating financial institutions and units that can effectively lend resources to facilitate the production of farm produce, crops and livestock. These markets are primarily made up of deposit money banks (DMBs) and other financial institutions, firms and individuals (Comptrollers Handbook, 1998).

However, the market also includes specialized institutions such as Bank Of Agriculture (BOA), which is the principal institution involved in agricultural financing in Nigeria. The banks have been playing prominent role and will continue to do so under a package of incentives. The life insurance companies can find useful avenues to invest their long-term funds by buying equipment for hire. However, for lenders in the formal financial market, the most significant risk is credit risk, which could arise from a number of factors ranging from bad harvest to poor market prices. However underwriting or guarantee can adequately address this. Other risks faced by lending in this market are liquidity, price, strategic and interest rate risks.

From 1978 to 1989 with sectoral credit allocation to the agricultural sector in place, the result was a consistent increase in the lending portfolios of formal financial institutions to the agricultural sector. This has now been lost to the financial system deregulation as agricultural lending is considered more risky, problematic and unprofitable relative to other sectors. Bank credits to this sector in nominal terms, over the years have increased from about $\mathrm{A} 230$ million (then about $\$ 2.33$ million) in 1978 to over $\mathbb{N} 262$ billion ( $\$ 2.23$ billion) in 2005 , but then food imports cost have equally increased (CBN, 2007).

For bank credit to be effective there must be soft landing for both the bank and the farmer in terms of cost and tenure. Ojo (2002) discusses the ineffective role of the erstwhile community banks in financing agriculture, having been transformed in 2007 to microfinance banks. Though Olaitan (2006) believes that this would enhance agricultural lending, this might not be so in the long-term given the attitude of this group of institutions over the years.

Credit guarantees ensure repayment of loans in part or full in order to motivate lenders to provide loans to borrowers who would otherwise not have been able to access credits on their own for reasons of unavailable financial records, lack of adequate collateral and the level of risks to be assumed by the lender (Navajas, 2001).

The Nigerian Agricultural Cooperative and Rural Development Bank (NACRDB) now Bank of Agriculture (BOA) is one of the government publicly sponsored credit institutions established since 1973 (formerly called the Nigerian Agricultural and Cooperative Bank) to cater for the credit needs of the agricultural sector. Unfortunately, the performance of NACRDB has been rated low, mainly due to high default rate by beneficiaries (Zeller, 2001). Oboh and Ekpebu (2011) used ordinary least square to examine the determinants of formal agricultural credit allocation to the farm sector in Nigeria. The study found out that there is the need to critically assess factors affecting the rate of credit 
allocation by beneficiaries of NACRDB. A detailed understanding of these factors may provide necessary information towards designing a more effective and sustainable credit system that can serve poor farmers better. Akintola (2004) used autocorrelation to carry out a study on the role of banking industry in financing agriculture. He identified banks' traditional roles to include financing of agriculture, manufacturing and syndicating of credit to productive sectors of the economy. Adekanye (2005) used panel data threshold to examine the role of banks on the growth of Nigerian economy. The study observed that in making credit available, banks are rendering a great social service, because through their actions, production is increased, capital investment are expanded and a higher standard of living is realized.

\section{RESEARCH METHODOLOGY}

\subsection{Study Area}

The study was carried out in Federal Republic of Nigeria. Nigeria is derived from the word 'Niger' which is the name of the river that constitutes the most remarkable geographical feature of the country. The country is located in Western part of Africa and is bordered by Cameroon and Chad in the east, Benin in the west, Niger in the north, Gulf of Guinea in the south and Lake Chad in the northeast. Nigeria is located between latitudes $4^{\circ} \mathrm{N}$ and $14^{\circ}$ North longitudes $2^{\circ} \mathrm{E}$ and $15^{\circ}$ East covering a geographical area of 923,768 square kilometers. The population according to NPC (2006) census was $140,003,542$ million. The climate is semiarid in the north and becomes increasingly humid in the south. Rainfall is one of the important climatic factors influencing agriculture and three broad ecological zones are commonly distinguished: the northern Sudan savannah $(500-1000 \mathrm{~mm})$, the guinea savannah zone or middle belt $(1,000-1,500 \mathrm{~mm})$ and the southern rainforest zone $(1,500-4,500 \mathrm{~mm})$. Generally, rainfall patterns are marked by an alteration of wet and dry seasons of varying duration. In the north, rainfall lasts from May to September with a peak in August, while in the south, rainfall is bimodal, increasing steadily from January and reaching its peak in September. About two thirds of the area cropped is located in the north with the rest equally divided between the middle and southern zones (ADB, 2006).

The average population density of 118 persons per square kilometer masks the disparity that exists between the densely populated South west of Nigeria, where much of the urban population live and the less concentrated north. The economy is characterized by a large rural population, mostly agricultural based traditional sector and relatively smaller urban, more capital intensive sector. The average per capita income (estimated by the World Bank in 2006) was US $\$ 300$ per annum (Coker, 2008).

\subsection{Method of data collection}

Data for this study was culled from secondary sources. The data provided information covering the period 19922012 and was gathered from various issues of annual reports and statement of account of Central bank of Nigeria and other relevant financial data in statistical bulletins of other local and international agencies. Consequently, time series data between 1992- 2012 on interest rate (lending rate), Cumulative foreign private investment in Agriculture, Index of Agricultural Gross Domestic Product (IAGDP), Liquidity ratio, Cash Reserve Ratio, Minimum Rediscount Rate, Index of world Agricultural commodity prices in naira per tonne were obtained and fitted to a model.

\subsection{Method of Data Analysis}

In order to realize the study objectives, a number of statistical tools were employed in analyzing data obtained for the study. Descriptive statistics such as frequency tables and percentages were used to analyze objectives (i). Two Stage Least Square regression technique was used to analyze factors influencing the volume of formal funds supplied to agricultural production in Nigeria (objective ii).

\subsection{Model specification}

The linear trend equation for estimating agricultural growth is specified in line with Ghosh (2010) as:

LnQt $=a+$ bt $+U_{t}$

\section{Where}

Qt $=$ funds allocation to food and cash crop production from formal supply at period $t$

$a=$ the constant in the regression line

$\mathrm{bt}=$ the estimate of the absolute increase in fund allocation to food and cash crop

$\mathrm{Ut}=$ the error term

However, for measuring the acceleration or deceleration in the growth rate, log quadratic trend equation was fitted and stated thus,

LnQt $=\mathrm{a}+\mathrm{bt}+\mathrm{ct}^{2}+\mathrm{Ut}$

A positive significant value of $c$ indicates acceleration while a negative significant value implies

A deceleration. A non - significant value shows stagnation in the growth process.

The compound growth rate equation is given as follows:

$\left.\begin{array}{llllll}r & = & (\mathrm{eb} & - & 1\end{array}\right)$

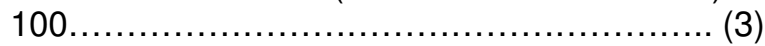


Where e is Euler's exponential constant (2.71828). This is in line with Onyenweaku (1993; 2004).

Most of the time series variables are non--stationary. To check for the unit-root in the variables there are many alternatives. However, the most recommended methods are the Augmented Dickey---Fuller (ADF) test and the Phillips-Perron (P-P) test. Testing for stationary series or unit roots are pre-tests before starting co-integration tests and applying the 2SLQ model because unit root processes provide the basis for statistical inference about the empirical existence of unit root and cointegration. The first formal test of the unit root null hypothesis was proposed by Dickey and Fuller (1979), known as Dickey-Fuller (DF) test. This test is based on independently and identically distributed (iid) errors. The DF test was later modified allowing some heterogeneity and serial correlations in errors, which is called augmented - DF (ADF) test.

The general model for the Augmented Dickey-Fuller (ADF) test is given by

$$
\Delta y \mathrm{t}=\alpha+\beta \mathrm{t}+\gamma_{\mathrm{t}-1}+\sum_{\mathrm{i}=1}^{\mathrm{p}} \delta_{\mathrm{i}} \Delta \mathrm{y}_{\mathrm{t}-1}+\xi_{\mathrm{t}} .
$$

where yt is the variable under investigation and $\xi_{\mathrm{t}} \sim$ iid $\left(0, \sigma^{2}\right)$. The summation terms in are the lagged first differences of the dependent variable to capture auto correlated omitted variables that would otherwise enter the error term. Stationarity is confirmed when the test statistic is greater than the critical value in absolute terms.

Also in the bid to ascertain the existence of long - run relationship, the cointegration test was performed using both the ADF and PP test (See Appendix). This was to confirm that the residuals of the non - stationary series that are 1(1) are actually 1(0). Prior to the cointegration test, the ordinary least squares estimation was performed on the variables in levels and the residuals tested for the presence of unit roots. If both the ADF and PP statistics are significant and also greater than the critical values in absolute terms, then there is presence of cointegration which is evident by the stationarity of the residuals of the static regression.

In realizing objective (ii), two stage least squares (2SLS) procedure was employed., The model is implicitly specified in line with Udensi et al, (2013) Thus,

$$
\begin{aligned}
& \mathrm{TCR}=\mathrm{f}(\mathrm{IR}, \mathrm{FPI}-\text { Agr }, \text { IAGDP, LR, CRR, MRR, WP, } \mathrm{T}) \\
& \text { (4) } \\
& \text { IAGDP }=f(I R, G E A, E X R, R I, T C R, L R, C R R, M R R, T) \\
& \text { (5) }
\end{aligned}
$$

Where:

$\mathrm{TCR}=$ Total credit accessed by farmers from commercial banks, NACRDB and Microfinance banks in naira to the Agricultural sector;
IAGDP $=\quad$ Index of Agricultural Gross Domestic Product; $\mathrm{FPI}_{\text {-Agr }}=\quad$ Cumulative Foreign Private Investment in Agriculture in naira;

EXR = Nominal exchange rate in Naira per US dollar $(\mathrm{N} / \$)$;

GEA = Total Government Expenditure in Agriculture in naira;

$\mathrm{IR}=$ Interest rate (lending rate) in percent

$(\%)$;

$\mathrm{RI} \quad=\quad$ Annual rate of inflation in percent (\%);

$\mathrm{WP}=$ Index of World Agricultural Commodity

Prices in Naira per Tonne ( $\mathrm{N} /$ ton);

$\mathrm{LR}=\quad$ Liquidity Ratio of commercial banks in percent (\%);

CRR $=$ Cash Reserve Ratio of commercial banks in percent (\%);

MRR = Minimum Rediscount Rate of commercial banks in percent (\%);

$\mathrm{T} \quad=\quad$ Time Trend variable in years (Yrs);

According to Gujarati (2006) and Koutsoyiannis (2001), in simultaneous equation models, unlike single equation models, what is a dependent (endogenous) variable in one equation appears as an explanatory (exogenous) variable in another equation. Thus, there is a feedback relationship between the variables. This feedback creates the simultaneity problem, rendering OLS inappropriate to estimate the parameters of each equation individually.

To begin, an intercept and coefficients were added to 4 and 5 resulting in structural equations

$$
\begin{aligned}
& \text { TCR }=\alpha_{0}+\alpha_{1} I R+\alpha_{2} \text { FPI-Agr }+\alpha_{3} I A P+\alpha_{4} L R+\alpha_{5} C R R+ \\
& \alpha_{6} M R R+e i \quad--(6) \\
& I A G D P=\beta_{0}+\beta_{1} G E A+\beta_{2} E X R+\beta_{3} I R+\beta_{4} R I+\beta_{5} C R+ \\
& \beta_{6} \text { FPI-Agr }+\beta_{7} W P+\text { ei -- (7) }
\end{aligned}
$$

From the simultaneous equations above, the endogenous variables are TCR, IAGDP, and IR while the pre-determined variables are IR, FPI-Agr, IAP, LR, CRR, MRR, GEA, EXR, RI, CR, and WP

\section{Let $\mathrm{TCR}=\mathrm{IAGDP}$}

The endogenous variables are expressed as a function of the pre-determined variables only to get the reduced form equations

$\mathrm{IR}=\prod_{10}+\prod_{11} \mathrm{GEA}+\prod_{12} \mathrm{EXR}+\prod_{13} \mathrm{RI}+\prod_{14} \mathrm{CR}+\prod_{15} \mathrm{FPI}$. Agr $+\prod_{16} \mathrm{WP}+\prod_{17} \mathrm{IAP}+\prod_{18} \mathrm{LR}+$

$\prod_{19} \mathrm{CRR}+\prod_{20 \mathrm{MRR}}+\mathrm{U}_{1}$ (8) 
$\mathrm{TCR}=\prod_{30}+\prod_{31} \mathrm{GEA}+\prod_{32} \mathrm{IAGDP}+\prod_{33} \mathrm{EXR}+\prod_{34} \mathrm{RI}+$
$\prod_{35} \mathrm{CR}+\prod_{36} \mathrm{FPI}$-Agr $+\prod_{37} \mathrm{WP}+\prod_{38} \mathrm{IAP}$
$+\prod_{39} \mathrm{LR}+\prod_{40} \mathrm{CRR}+\prod_{41} \mathrm{MRR}+\mathrm{U}_{\mathrm{I}}$ (9)

IAGDP $=\prod_{50}+\prod_{51} \mathrm{GEA}+\prod_{52} \mathrm{TCR}+\prod_{53} \mathrm{EXR}+\prod_{54} \mathrm{RI}+$
$\prod_{55} \mathrm{CR}+\prod_{56} \mathrm{FPI}_{\text {-Agr }}+\prod_{57} \mathrm{WP}+\prod_{58} \mathrm{APP}$
$+\prod_{59} \mathrm{LR}+\prod_{60} \mathrm{CRR} \underset{+}{+} \prod_{61} \mathrm{MRR}+\mathrm{U}_{\mathrm{I}}$

Apply OLS to the reduced form equations to generate the estimated parameter, IR (Stage one). This estimated interest IR replaces the original IR in the structural equation to get consistent and unbiased estimates (Stage two).

$$
C R=f(I R, F P I-A g r, I A G D P, L R, C R R, M R R, W P T)
$$

\section{RESULTS AND DISCUSSION}

\subsection{Sub-sectoral Conduct and Performance of the Formal Credit Sources by Amount of Loan Disbursed to Agriculture within 1992- 2012.}

The performance of the formal credit sources (Bank of Agriculture (BOA), Micro-finance banks and commercial banks) by amount of loan disbursed to agriculture from
1992 to 2012 is displayed in Table 1 . Table 1 revealed that commercial banks under the ACGS performed better than the Microfinance banks and Bank of Agriculture. Table 1 showed that commercial banks disbursed as high as $\mathbf{4 8 . 8 b n}$, with Microfinance banks disbursing $\mathrm{N} 32.3 \mathrm{~m}$ and $\mathrm{BOA}$ disbursing $\mathrm{N} 14.7 \mathrm{~m}$ to agriculture over the period under review. The relatively high amounts of loan disbursed by the commercial banks were to the medium and high scale operating farmers. These categories of farmers were able to meet the lending conditions especially the collaterals required.

Comparatively, the Microfinance banks performed better than BOA in amounts of funds disbursed annually to their target farmers. Cumulatively, the loans supplied to agriculture by micro finance bank within the period showed upward trend as the years passed by with annual mean loan size of $\mathrm{N} 1.54 \mathrm{~m}$. The difference between the minimum ( $\mathbb{N} 29,500$ million supplied in 1992) and maximum ( $\mathrm{N}$ 5,96m supplied in 2009) was $A 5,928.300$ an amount that was a very high range within the period under review.

Similar cumulative increase were also recorded in the volume of loan supplied to agriculture by commercial banks with an annual average and corresponding standard deviation of

A 2, 323,719.000.00 and A 3, 485,746000.00 respectively. The gap between the minimum (AN9, $104,900.00$ in 1992) and maximum ( $\mathbf{N 1 0 , 1 9 3 , 8 4 7 0 0 0 . 0 0}$ in 2011) values of fund supplied to agriculture within the period under review was quite large in an upward trend from commercial banks. 
Table 1: Performance of Formal Credit Sources by Amount of loan disbursed to Agriculture from 1992 to 2012 (N 000 )

\begin{tabular}{llll}
\hline & Bank of & & \\
Year & Agriculture & Microfinance Banks & Commercial banks \\
\hline 1992 & 3234.2 & 29.5 & 9104.9 \\
1993 & 4715.5 & 123.2 & 80969 \\
1994 & 5947.4 & 155.4 & 32183.8 \\
1995 & 414.2 & 98.6 & 44314.7 \\
1996 & 410.4 & 229.4 & 33489.6 \\
1997 & - & 367.4 & 27939.7 \\
1998 & - & 962.7 & 27180.7 \\
1999 & - & 1007.2 & 364600.8 \\
2000 & - & 656.6 & 507954.9 \\
2001 & - & 77.6 & 929401.6 \\
2002 & - & 390.5 & 1279207 \\
2003 & - & 625 & 242185.7 \\
2004 & - & 483.31 & 261558.6 \\
2005 & - & 69.9 & 3308744 \\
2006 & - & 956.1 & 4312450 \\
2007 & - & 2245.2 & 149570 \\
2008 & - & 3534.3 & 6827425 \\
2009 & - & 5957.8 & 8485209 \\
2010 & - & 5102.9 & 1774884 \\
2011 & - & 4679.22 & 10193847 \\
2012 & - & 4511.68 & 9905881 \\
Total & 14721.7 & 32263.51 & 48800000 \\
Mean & 701.0333 & 1536.358 & 2323719 \\
Standard dev & 1704.217 & 1950.139 & 3485746 \\
Minimum & 3234.2 & 29.5 & 9104.9 \\
Maximum & 5947.4 & 5957.8 & 10193847 \\
\hline & & $\$ 04.9$ &
\end{tabular}

Source: Computed from CBN data, 2012.

Three- year averages of the performance of formal credit sources by amount of loan disbursed to agriculture from 1992 to 2012 (Table 2) showed that the amount of loan disbursed to agriculture by Micro-finance bank and commercial bank followed similar trend. Both loan sources peaked their supplies sharply on two occasions 2007-2009 and 2010-2012. The credit data from bank of Agriculture was inconsistent and information for many years was unavailable.

Table 2: Three-year Averages of Performance of Formal Credit Sources by Amount of Loan Disbursed to Agriculture from 1992 to 2012

\begin{tabular}{llll}
\hline Year & Bank of Agriculture & Microfinance Bank & Commercial bank \\
\hline $1992-1994$ & 4632.3 & 102.7 & $40,752.56$ \\
$1995-1997$ & 274.9 & 231.8 & 35,248 \\
$1998-2000$ & - & 875.5 & $299,912.13$ \\
$2001-2003$ & - & 364.36 & $816,931.43$ \\
$2004-2006$ & - & 503.10 & $2,627,584.2$ \\
$2007-2009$ & - & $3,912.43$ & $5,154,068$ \\
$2010-2012$ & - & $4,764.6$ & $7,291,537.3$ \\
\hline
\end{tabular}




\section{2: Determinants of Volume of Funds Supplied to Agricultural Production from Formal Sources by Two Stage Least Squares (2SLS)}

The unit root results, prior to credit supply estimation using two stage least squares (2SLS), revealed that the test variables were stationary at first difference. Cointegration was confirmed with the application of ADF and PP tests on the residuals (see appendix) while Hausman specification test was done to ascertain the existence of simultaneity. Having established that the model was over identified after the simultaneity test, the two-stage least squares (2SLS) method was used to estimate the model. This was to realize unbiased and consistent estimates and the results are presented in Table 3 . In the supply relation, the coefficient (1.708848) of interest rate was positive and statistically significant at $1 \%$ probability level. The positive sign implies that the volume of funds supplied to agricultural production from formal sources in Nigeria increased as interest rate increased.

The direct relationship between interest rate on lending and volume of fund supplied to agricultural production is in tandem with the theory of supply as reported by Adegeye and Dittoh (1985). This implies that any unit increase in percentage of interest rate (IR) spurred a corresponding 1.708848 million Naira increase in the total credit supplied to farmers from formal credit sources. Olokoyo (2011) reported a similar positive though non-significant correlation between interest rate and credit accessed by farmers in Nigeria. Also, Udensi et al; (2013) reported a similar positive but significant correlation between IR and TCR. Nevertheless, this empirical evidence could be a result of that high lending nominal interest rate which spurs marginal willingnessto-lend by formal credit sources. In addition, formal credit institutions still have the highest market share in Nigeria.

The estimated coefficient (5216.525) of commercial banks' liquidity ratio (LR) was found to be positively related to total banks' credit accessed by farmers and statistically significant at $1.0 \%$ alpha-level of probability. This conformed to a priori expectation and the findings of Olokoyo (2011). It implies that a marginal increase in banks liquidity ratio will spur a corresponding 5216.525 million Naira increase in the volume of funds supplied to agricultural production from formal sources. Therefore, policy makers and stakeholders (commercial banks, microfinance Banks, Bank of Agriculture) need to strategize on effective means of raising banks' liquidity in a way that will increase their loan disbursement ability to farmer borrowers without, jeopardizing the general price level in the economy and other cardinal macroeconomic indicators of the economy.

The parameter estimate of banks' cash reserve ratio (CRR) (-90609.99) was found to be negatively related to total credit accessed by farmers from formal credit institution (CR) and statistically significant at 1.0\% $\alpha$ - level. This is in line with a priori expectation. It implies therefore, that any unit increase in banks' cash reserve ratio (CRR) will necessitate a corresponding 90609.99 million Naira decrease in banks' loans to farmers (CR).

This result is contrary to Olokoyo (2011); Udensi et al (2013) that reported a positive relationship between CRR and TCR and stated that due to the fact that most commercial banks in Nigeria when faced with a decline in core deposits as a result of tight monetary policies in form of high reserve requirement tend to balance the loss of deposits by selling securities and obtaining additional funding in order to continue to meet loan demand.

The estimated coefficient (-684.5361) for Index of World Agricultural Commodity Prices (WP) were negatively related to $C R$ and Significant at $1 \% \alpha$ - level except for IAP that was significant at $5 \% \alpha-$ level. These conformed to their respective a priori expectations. In other words, a marginal increase in the values of World Agricultural Commodity Prices will, at constant values of the other explanatory variables, induce a corresponding N14.4 million decreases in the total credit supplied to farmers by formal institutions. This is however contrary to a priori expectation and terms of the diagnostic statistics, the supply relation had appreciable $R^{2}$ (0.7904) estimates and $F$ - ratios (6.46), implying reasonable explanation of variations in the overall significance of the model. The DW estimates (2.323311) showed absence of autocorrelation in the model given that they fell within $1.5-2.5$ range. Based on the findings shown in Table 3, the null hypothesis that Total farm credit accessed from commercial banks, NACRDB and micro finance bank is not significantly influenced by interest rate (lending rate) in percentage (IR), Cumulative foreign private investment in Agriculture in naira (FPI-Agr), Index of Agricultural Gross Domestic Product (IAGDP), Liquidity ratio of commercial banks in percentage (LR), Cash Reserve Ratio of commercial banks in percentage (CRR), Minimum Rediscount Rate of commercial banks in percentage (MRR), Index of world Agricultural commodity prices in naira per tonne (WP) and Time Trend variable in years (T) is rejected. 
Table 3: Two-Stage Least Square Estimates of Factors that influenced the Volume of Funds Supplied to Agricultural production from formal sources in Nigeria from 1992 to 2012.

\begin{tabular}{lllll}
\hline Variable & Coefficient & Std. Error & t- Statistic & Prob. \\
\hline CONSTANT & 4397552 & 5245791 & 0.84 & 0.418 \\
IR & $1.708848^{\star \star *}$ & 0.2924653 & 5.84 & 0.000 \\
CFPIA & 345.2626 & 2927.531 & 0.12 & 0.908 \\
IAGDP & 11214.95 & 26998.27 & 0.42 & 0.685 \\
LR & $5216.525^{\star * *}$ & 1584.311 & 3.29 & 0.006 \\
CRR & $-90609.99^{\star * *}$ & 12171.8 & -7.44 & 0.000 \\
MRR & 21908.49 & 143100.2 & 0.15 & 0.881 \\
WP & $-684.5361^{\star *}$ & 276.3906 & -2.48 & \\
R $^{2}$ & 0.7904 & & & \\
Adjusted R & 0.6681 & & & \\
F-Statistics & $6.46^{\star * *}$ & & & \\
DW & 2.323311 & & & \\
\hline
\end{tabular}

Source: Output of Analysis from Stata (2014)

${ }^{* * *},{ }^{* *}$ and * represent significance at $1 \%, 5 \%$ and $10 \%$ probability levels respectively

\subsection{CONCLUSION}

Based on the empirical findings of the study, it is adduced that in terms of performance of formal credit sources by amount of loan disbursed to agriculture commercial banks under the ACGS performed relatively better than the Microfinance banks and Bank of Agriculture which was evident by the amount disbursed ( $\$ 48.8 \mathrm{bn}$ ) by commercial banks, with Microfinance banks disbursing $\$ 32.3 \mathrm{~m}$ and BOA disbursing $\$ 14.7 \mathrm{~m}$ to agriculture over the period under review and volume of funds supplied to agricultural production from formal sources was influenced by interest rate, commercial banks' liquidity ratio, banks' cash reserve ratio (CRR) and index of World Agricultural Commodity Prices.

\subsection{RECOMMENDATIONS}

Based on the findings of this study and conclusions drawn, a number of policy implications and recommendations are made towards ensuring efficient Agricultural credit delivery as well as growth and development of agriculture in Nigeria.

First, Nigerian Government must consider interest rate regulation as a veritable tool for making credit accessible to farmers at affordable levels where transaction costs will not be too high as to discourage farmers willing to invest or expand their investment to withdraw from doing so.

Nigerian government should develop pro-active pro-farmer synergies with her monetary policies in such a way that will increase banks' marginal propensity to lend for extra unit of loan demanded by farmers without jeopardizing the general price level and other cardinal macroeconomic objectives of the federal government. This can be achieved by systematically lowering the discount rate and reserve requirement which will increase commercial banks' liquidity and maintain a considerable amount of interest rate that will neither be too high for farmers to borrow nor too low for commercial banks to lend.

In addition the Central Bank of Nigeria needs to increase its monitoring capacity on banks generally and strengthening of the microfinance banks with a view of encouraging them to advance more loans to the agricultural sector.

\section{REFERENCES}

African Development Bank (ADB) (2006). National Programme for Food Security (NFPS). Staff Appraisal Report.

Adegeye, A.J. and Dittoh J.S. (1985). Essentials of Agricultural Economics. Impact Publishers Nigeria Limited, Ibadan.

Adekanye, F. (2005). Elements of Banking in Nigeria, Lagos: $\mathrm{F}$ and A Publisher. Agricultural development: a case study of small-scale food production in Ondo State, Nigeria. Samaru Journal of Agricultural Education, 3 (1 and 2), 29-35.

Akintola, S. (2004). Banks Move against Soludo. Nigerian Tribune (July 23rd), p. 24.

Akpan, H. E. (1999). Public Expenditure and Economic Growth in a Petroleum Based Economy: Nigeria (1960-1992). International Journal of Social Sciences, Faculty of Social Sciences, University of Uyo, Vol. 1.

Asuquo, I., Ofem, U., and Ajah, E. (2014). Credit Reserve and the Demand for Agricultural Loans in Cross River State, Nigeria. Journal of Biology, Agriculture and Healthcare. 4(16): 17 - 22. 
Central bank of Nigeria (CBN), (2003). Agricultural Development: Issues of Sustainability. In: O.I. Nannna, S.O. Alade.

E. O. Odoko (Eds.): Cotemporary Economic Policy Issues in Nigeria. Abuja: CBN Publications, pp.185222.

CBN, (2005). Statistical Bulletin. CBN. Abuja

CBN, (2006a). Economic and Financial Review Vol, 25.No.4.

CBN, (2006b). CBN Statistical Bulletin Vol.15 December 2006.

CBN, (2007a). Statistical Bulletin, Abuja: CBN Publications.

CBN. (2007b). Annual Report and Statement Account. December 2007. Abuja. Nigeria.

CBN. (2007c): Agricultural Credit Guarantee Scheme Fund of Nigeria (ACGSF): An impact assessment. Study conducted by Centre for resource Analysis and Management for the Governing Board of the ACGSF, Abuja.

CBN. (2010). Developments in the External Sector. External Sector Committee Reports, Quarter3, Issue 1 No. 3, P. 6.

CBN. (2012). Central Bank of Nigeria Annual Report 2012. Pp.157-159.

Central Bank of Nigeria (2012): Statistical Bulletin. Central Bank of Nigeria, Abuja, Nigeria.

Coker, A.A. (2008). Empirical Analysis of Federal Government Expenditure Policy on Agriculture in Nigeria (1960 - 1998). Ph.D thesis, Department of Agricultural Economics, University of Nigeria, Nsukka.

Comptroller's Handbook, (1998). Agricultural Lending. Comptrollers of Currency and Administrator of National Bank. New York. Federal Reserve Bank.

Egbe, A.B. (1990). "Financial Institutions and Agricultural Finance: The Role of CBN". Proceedings of a seminar organized by the CBN, CBN Lagos.

Ghosh, B.K. (2010). Growth and Variability in the Production of Crops in West Bengal Agriculture. Trends in Agricultural Economics, 3(3): 135 - 146.

Gujarati, O. M. (2006). Essentials of Eonometrics. 3rd Ed. McGraw-Hill International: New York.

Koutsoyiannis, A. (2001). Theory of econometrics (2nd Edition.). Palgrave: New York. Pp 346-395.

National Population Commission (NPC). (2006). Census Report. National Population Commission (NPC). Abuja, Nigeria.

Navajas, A. R, (2001). Credit Guarantee Schemes Conceptual Framework: Financial System Development Project. Technical Bulletin No. 1. Bolivia - June Publication of GTZ/FONDESIF.
Nwaru, J. C, Onyenweaku, C. E.; Nwagbo, E. C and Nwosu, A. C. (2004). Determinants of Rural Farm Loan Repayment: Implications for Rural Credit Markets Development in Imo State, Nigeria. Journal of Agriculture and Food Sciences, 2(1): 48-58.

Oboh, V. U. (2008). Farmers' allocative behavior in credit utilization: a case study of arable crop farmers in Benue State, Nigeria. PhD dissertation, Agricultural Economics and Extension Programme, Abubakar Tafawa Balewa University, Bauchi, Nigeria.

Oboh, V. U. and Ekpebu, 1. D.(2011). Determinants of formal agricultural credit allocation to the farm sector by arable crop farmers in Benue State, Nigeria. African Journal of Agricultural Research, 6(1), 181185.

Ogiri, P. (2004). Agriculture and the Food basket Myth; Implication for Food Security and Agricultural Policy Reforms in "Nigeria. Markurdi, Aboki Publishers.

Oguamanam, H. M. (1996). "Commercial Bank Credit to Agricultural Sector in Nigeria". Paper presented at The $17^{\text {th }}$ Annual Conference of CBN Agricultural Credit Officers held at Hill Station Hotel, Jos.

Ojo A. T. (2002). The future of community banks in Nigeria. First Bank of Nigeria Plc Quarterly Review, 2: 45-61.

Onoja, A.O., Onu, M E. and Ajodo-Ohiemi, S. (2013). Contributions of Financial Sector Reforms and Credit Supply to Nigerian Agricultural Sector (1978-2009). Central Bank of Nigeria Journal of Applied Statistics. Vol. 2, No. 2.

Olaitan M A, (2006). Financing for small and medium enterprises Nigeria's agricultural credit guarantee scheme fund. Journal of International Farm Management, 3(2): 1-9.

Olokoyo. F. 0. (2011). "Determinants of Commercial Banks' lending Behaviour in Nigeria". International Journal of Financial Research, Vol. 2(2): Pp. 45-53.

Onyenweaku, C.E. (1993). Investigation of the Hypothesis of Deceleration in Crop Production in Nigeria, 1960/61 - 1987/88, Modeling Simulation and Control D. France, 7(1): 27 - 40.

Onyenweaku, C.E. (2004). Stagnation, Acceleration and Deceleration in Agricultural Production in Nigeria, 1970 - 2000. Journal of Agriculture and Food Science, 2(2): $131-140$.

Udensi A.I., Anyiro C.O., Orebiyi J.S., Eze C.C., Ohajianya D.O and Ezeh C.I (2013). Farmers' Credit Stock Determinants from Commercial Banks and its Effects on Agricultural Production in Nigeria. World Research Journal of Tropical Agriculture.1(2):27-30. 


\section{APPENDIX}

\section{Preliminary Tests (Stationarity, Cointegration and Simultaneity Tests)}

The variables for fund supply function from formal sources were subjected to stationarity and cointegration tests in line with time series econometrics and their results presented in appendix Tables 1.1 and 2.1 respectively. Appendix Table 1.1 showed that all variables subjected to ADF unit root test were not stationary in their level form at all alpha levels of significance. On application of the ADF test to their first difference terms, they became stationary as shown by the values of the ADF test, which are larger (in absolute terms) than the standard critical values.
To also confirm stationarity, the variables were also subjected to Philips-perron (PP) test which was believed to give robust estimates. All the variables became stationary in their first difference terms. Hence, they are integrated of first order.

The cointegration test was preceded by the performance of ordinary least squares (OLS) estimation on the variables and tested at different alpha levels of significance. The residuals generated from the OLS estimation were subjected to the cointegration test. The results of the cointegration test for the supply relation is presented in appendix Table 2.1.

Table 1.1. Augmented Dickey-Fuller (ADF) and Phillips-Perron (PP) Tests for Integration Order for total credit supply determinants

\begin{tabular}{|c|c|c|c|c|}
\hline \multicolumn{3}{|c|}{$\begin{array}{r}\text { Augmented Dicky- } \\
\text { Fuller (ADF) }\end{array}$} & \multicolumn{2}{|c|}{ Philips Perron (PP) } \\
\hline Variables & Level & $\begin{array}{l}\text { First } \\
\text { Difference }\end{array}$ & Level & First Difference \\
\hline IAGDP & 1.121 & $-5.739^{* * \star}$ & 1.643 & $-6.279^{\star \star \star}$ \\
\hline FPI-Agr & -0.311 & $-4.796^{\star \star \star}$ & -1.445 & $-4.749^{\star \star \star}$ \\
\hline IR & -2.523 & $-4.992^{\star \star *}$ & -2.523 & $-4.908^{\star \star \star}$ \\
\hline WP & -2.187 & $-4.186^{* *}$ & -2.187 & $-4.187^{\star *}$ \\
\hline LR & -2.655 & $-4.675^{\star \star \star}$ & -2.655 & $-4.695^{\star \star \star}$ \\
\hline CRR & -2.215 & $-6.335^{\star \star \star}$ & -2.215 & $-6.207^{\star \star *}$ \\
\hline MRR & -2.475 & -7.655 & -2.475 & $-7.275^{\star \star \star}$ \\
\hline
\end{tabular}

Source: Output of Results from Stata 11(2014)NB: Critical values of ADF at $\left.1 \%{ }^{* * *}\right), 5 \%\left(^{* *}\right)$ and $10 \%\left({ }^{*}\right)$ are $-4.187,-3.516$ and -3.190 respectively. The PP test critical values at $1 \%\left({ }^{* * *}\right), 5 \%\left({ }^{* *}\right)$ and $10 \%\left({ }^{*}\right)$ are $-4.196,-3.520$ and -3.192 respectively.

The result of the residual-based cointegration test showed that the regression residuals of the supply function were stationary. Both the ADF and PP tests were applied but the critical values of the latter were relied upon. Dittmann (2002) argued that Phillips-Perron test when applied to residual-based cointegration determination is more powerful than the ADF test. Based on the critical values, it could be inferred that there existed a cointegration relationship in the supply relation equations for the agricultural credit.

Table 2.1. Results of Residual-based Cointegration Test

\begin{tabular}{lcc}
\hline Variable & ADF & PP \\
\hline Residual & -5.505 & -5.507 \\
\hline \multicolumn{2}{c}{ NB: Critical values at $1 \%\left({ }^{* * *}\right), 5 \%\left(^{* *}\right)$ and $10 \%\left(^{*}\right)$ are $-2.631,-1.950$ and -1.607 respectively. }
\end{tabular}

Prior to estimation and given that Total credit accessed by farmers (TCR) was potentially endogenous because of the presence of simultaneous relationship with $C D$,
Hausman specification test was performed and the result shown in Table 4.11. It showed that there was simultaneity since the results are significant and null 
hypothesis of no simultaneity between TCR and CD rejected at $1 \%$ levels of probability.

Table 3.1: Results of Simultaneity

Variable endogenous
Test Statistics

$14.604^{\star \star \star}$

Simultaneity

Source: Output of Results from Stata (2014) 